\title{
FZD8 Gene
}

National Cancer Institute

\section{Source}

National Cancer Institute. FZD8 Gene. NCI Thesaurus. Code C104403.

This gene plays a role in cell signaling. 